\title{
Eosinophilic pleural effusion in an eleven-year-old boy
}

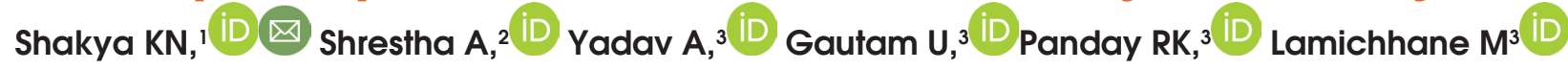

${ }^{1}$ Kashyap Narsingh Shakya, Professor; ${ }^{2}$ Anup Shrestha, Assistant Professor; ${ }^{3}$ Arabindra Yadav, ${ }^{3}$ Uttara Gautam, ${ }^{3}$ Rajesh Kumar Panday, ${ }^{3}$ Mira Lamichhane, MD Resident; Department of Paediatrics, Kathmandu Medical College Teaching Hospital, Sinamangal, Kathmandu, Nepal.

\begin{abstract}
Pleural effusion fluid with $\geq 10 \%$ eosinophils may be seen in $5-16 \%$ of exudative pleural effusions. Its association with helminthic infestation is reported in the literature. This patient with left-sided eosinophilic pleural effusion was a referred case from another hospital and treated initially as parapneumonic. With inadequate response to antibiotics and a markedly high lgE level praziquantel was started. This resulted in rapid disappearance of symptoms, decrease in the eosinophil count, and radiological improvement. After exclusion of parapneumonic, tuberculosis, autoimmune disease, and malignancy, a trial of antihelminthics should be considered an option. This may spare unnecessary investigations.
\end{abstract}

Key words: Eosinophilic; Helminthiasis; Pleural effusion; Praziquantel.

\section{INTRODUCTION}

W hen pleural effusion (PE) fluid contains $>10 \%$ eosinophils it is called eosinophilic PE. ${ }^{1,2}$ This accounts for $5-16 \%$ of exudative PE. ${ }^{2}$ The causes of PE in children are parapneumonic (50-70\%), congestive cardiac failure (5-15\%), and malignancy. ${ }^{3}$ Reports of paediatric eosinophilic PE are infrequently found in the literature. Reports are published regarding parasite infected ${ }^{4}$ or idiopathic ${ }^{5}$ cases. Association with subcutaneous cysticercosis, ${ }^{6}$ giardiasis, ${ }^{7}$ and idiopathic hypereosinophilic syndromes ${ }^{8}$ are reported. PE with helminthic infestation including paragonimiasis has

Access this article online

Website: www.jkmc.com.np

DOI: https://doi.org/10.3126/jkmc.v10i2.40063

HOW TO CITE

Shakya KN, Shrestha A, Yadav A, Gautam U, Panday RK, Lamichhane M. Eosinophilic pleural effusion in an eleven-year-old boy. J Kathmandu Med Coll. 2021;10(2):95-7.

Address for correspondence

Dr. Kashyap Narsingh Shakya

Professor, Department of Paediatrics,

Kathmandu Medical College Teaching Hospital,

Sinamangal, Kathmandu, Nepal.

E-mail: shakyakashyap@yahoo.com

Copyright @ 2021 Journal of Kathmandu Medical College (JKMC)

ISSN: 2019-1785 (Print), 2091-1793 (Online)

(i) (S) This work is licensed under a Creative Commons Attribution-Non Commercial 4.0 International License. been reported from developing countries. ${ }^{9}$ Here a case of eosinophilic PE in an eleven-year-old boy is presented.

\section{CASE REPORT}

An eleven years old male was admitted at Kathmandu Medical College Teaching Hospital, as a referral case from another hospital for fever and cough for 10 days and was not responding to treatment. When attended, he was febrile (temperature $101.8^{\circ} \mathrm{F}$ ), $\mathrm{SPO}_{2} 99 \%$ in room air. His chest X-ray showed left-sided pleural effusion. He was admitted as left-sided parapneumonic effusion and treated with ceftriaxone and vancomycin awaiting investigation reports (Table 1).

Although his fever subsided, cough and chest pain persisted which prompted a second line of investigations (Table 2).

Deworming was done with albendazole $400 \mathrm{mg}$ oral for three consecutive days. Because of markedly high immunoglobulin IgE level (as is seen in parasite infestation) he was treated with praziquantel for 14 days. The response was seen as a progressive reduction in eosinophil count (from $62 \%$ to $38 \%$ ) within a few days of therapy and a decrease in pleural effusion volume as estimated by ultrasonography. He was discharged on day 11 looking cheerful and asymptomatic.

At the follow-up visit, two weeks later, he had put on weight and maintained symptom-free. His eosinophil count had further decreased to $10 \%$ and had only a blunted costco- and cardio-phrenic angles radiologically 


\section{Table 1: Reports of initial investigation}

\begin{tabular}{ll}
\hline Investigation & Report \\
\hline Total leukocyte count & $21,410 / \mu \mathrm{L}$ or, $21.41 \times 10^{9} / \mathrm{L}\left(\mathrm{N}=4-11 \times 10^{9} / \mathrm{L}\right)$ \\
\hline Differential count & $\begin{array}{l}\text { Neutrophils - } 20 \%, \text { Lymphocytes }-18 \%, \text { Eosinophils - 62\%, } \\
\text { Absolute Eosinophil Count (AEC) } 15,134 / \mu \mathrm{L}\end{array}$ \\
\hline Platelets & $5,17,000 / \mu \mathrm{L}$ \\
\hline ESR & $55 \mathrm{~mm} / \mathrm{hr}$ \\
\hline Haemoglobin & $11.7 \mathrm{gm} / \mathrm{dL}$, \\
\hline C-reactive protein & $30 \mathrm{mg} / \mathrm{L}$ \\
\hline Random blood sugar & $93 \mathrm{mg} / \mathrm{dL}$ \\
\hline Peripheral blood smear & Eosinophilic leukocytosis with Neutrophils - 36 \%, Lymphocytes - 23\%, and Eosinophils - 41\% \\
\hline Stool examination & No abnormal cells or haemoparasites found \\
\hline Urinalysis & Ova of Ascaris \\
\hline
\end{tabular}

Table 2: Reports of second line of investigation

\begin{tabular}{|c|c|}
\hline Investigation & Report \\
\hline USG-guided pleurocentesis & Left-sided septated, pleural effusion \\
\hline \multicolumn{2}{|l|}{ Pleural fluid analysis } \\
\hline Sugar & $25 \mathrm{mg} / \mathrm{dL}$, \\
\hline Protein & $6.9 \mathrm{gm} / \mathrm{dL}$ \\
\hline Total cell count & $34 / \mathrm{mm}^{3}$ \\
\hline Differential cell count & Eosinophils $60 \%$, Lymphocytes $15 \%$, Neutrophils $25 \%$, no malignant \\
\hline Lactate dehydrogenase (LDH) & cells \\
\hline Adenosine deaminase (ADA) & $16.80 \mathrm{IU} / \mathrm{L}$ \\
\hline Pleural fluid LDH/Serum LDH & $26 \mathrm{U} / \mathrm{L}$ \\
\hline \multirow[t]{2}{*}{ XpertMTB/RIF test } & $5.36(>0.6)$ \\
\hline & Negative for Mycobacterium tuberculosis \\
\hline Mantoux test & No induration \\
\hline Sputum 3 consecutive specimens for AFB & AFB negative \\
\hline Antinuclear antibodies & Negative \\
\hline Serum Immunoglobulin E (lgE) & 4824.00 kUA/L (Reference : <85.00 kUA/L) \\
\hline Serum protein & $10.5 \mathrm{gm} / \mathrm{dL}$ \\
\hline Serum LDH & $313 \mathrm{IU} / \mathrm{L}$ \\
\hline Serum ADA & $26 \mathrm{IU} / \mathrm{L}$ \\
\hline Pleural fluid LDH/Serum LDH ratio & $5.36(>0.6)$ \\
\hline Pleural fluid protein/ Serum protein ratio & $0.6(>0.5)$ \\
\hline Light's criteria ${ }^{10}$ & Exudative pleural effusion \\
\hline
\end{tabular}

\section{DISCUSSION}

The patient was receiving antibiotics for respiratory symptoms, at presentation but did not respond adequately despite upgrading of antibiotics. Further investigations fulfilled criteria for exudative pleural effusion, ${ }^{10}$ associated with markedly elevated IgE level. The eosinophil count in the pleural effusion fluid was $60 \%$. After exclusion of tuberculosis and autoimmune aetiology, the helminthic infestation was considered as the most likely cause.
Helminthiasis is a macro parasitic disease in which part of the body is infested with helminths of which there are numerous species classified broadly into tapeworms, flukes, and roundworms. These infest mostly the gastrointestinal tract of the host but occasionally burrow into other organ systems causing lesions. They induce an immune response and immune-mediated inflammatory changes in the organs including the lungs and pleura, causing eosinophilia and oedema as the $T$ helper cells and eosinophils respond to helminth infestation. 
Pleural parasitic infestation (PPI) is a rare pleural disease caused by a variety of parasites, such as the lung fluke Paragonimus westermani, Toxocara spp., Clonorchis sinenis, Spirometra spp. and Taenia solium, etc. ${ }^{9}$ New cases are being reported in the literature. These may have pleural involvement only, or with other non-specific pulmonary manifestations.

Praziquantel (PZQT) is a pyrazinoisoquinoline with the chemical name 2-cyclohexylcarbonyl-1,2,3,6,7,11bhexahydropyrazino $(2,1-a)$ isoquinolin-4-one..$^{10}$ It is a broad-spectrum anthelmintic in use since 1980, with activity against trematode or cestode helminthic infestations. It has been used in the treatment of schistosomiasis in a large scale, and also for the treatment of cysticercosis and Hymenolepsis nana infestation as an off-label drug.

PZQT causes paralytic muscular contraction by increased intracellular $\mathrm{Ca}^{++}$influx and tegumental disruption and expels the worms from their primary habitat, after which they degenerate. ${ }^{11}$

In a retrospective series of $\mathrm{PPI}$, nine patients were treated with praziquantel which resulted in the resolution of symptoms and abnormal pleural/pulmonary radiographic features without recurrences. ${ }^{9}$

\section{REFERENCES}

1. Adelman M, Albelda SM, Gottlieb J, Haponik EF. Diagnostic utility of pleural fluid eosinophilia. Am J Med. 1984;77:915-20. [PubMed | Full Text | DOI]

2. Kalomenidis I, Light RW. Eosinophilic pleural effusions. Curr Opin Pulm Med. 2003;9(4):254-60. [PubMed | Full Text | DOI]

3. Efrati O, Barak A. Pleural effusions in the paediatric population. Pediatr Rev. 2002;23(12):417-25. [PubMed | Full Text]

4. Miao R, Zhu Y, Wang Z, Luo S, Wan C. Distinguishment of parasite-infected children from paediatric inpatients with both eosinophilia and effusion. Medicine (Baltimore). 2020;99(14):e19625. [PubMed |Full Text |DOI]

5. Luo W, Zeng Y, Shen P, He J, Wang J. Diagnostic procedure for idiopathic eosinophilic pleural effusion: A single-center experience. BMC Pulm Med. 2020 Apr 3;20(1):82. [PubMed | Full Text] | DOI]
In this patient, a therapeutic trial of praziquantel led to similar rapid recovery and convalescence. Eosinophilia (62\%) was present in the peripheral blood in our patient, which was present in only five of 11 cases in the retrospective series. ${ }^{9}$ The limitation of this report was that parasite-specific immunologic test and or detection of parasite eggs in the pleural effusion fluid could not be obtained. However, considering the possibility of helminthiasis as the cause of pleural effusion with eosinophilia in endemic areas spares the patient from unnecessary investigations. Moreover, this should be viewed in the context that parasitosis is a treatable condition. Delay in treatment may lead to prolonged morbidity or even preventable mortality.

\section{CONCLUSION}

Eosinophilic pleural effusion may result from parasitic pleural infestation. Possibility of parapneumonic, tuberculosis, autoimmune disease, and malignancy should be considered in the differential diagnosis of exudative pleural effusion. A trial of antihelmintic medication should be considered an option.

Conflict of interest: None

Source(s) of support: None
6. Salaria M, Parmar V, Kochar S, Mehta S. Eosinophilia, pleural effusion, and cysticercosis - Unknown association? Indian Pediatr. 2001 Jun;38(6):671-4. [PubMed | Full Text]

7. Singh U, Garg N, Chopra V. Eosinophilic pleural effusion and giardiasis: A causal or a casual relationship? Lung India. 2013; 30(1): 69-71. [PubMed | Full Text | DOI]

8. Okafor NC, Oso AA, Oranu AC, Wolff SM, Murray JJ. Eosinophilic pleural effusion: A rare manifestation of hypereosinophilic syndrome. Case Rep Med. 2009;2009:635309. [PubMed | Full Text | DOI]

9. Wang J, Luo W, Shen P, He J, Zeng Y. Retrospective study of pleural parasitic infestations: A practical diagnostic approach. BMC Infect Dis. 2019 Jul 4;19(1):576. [PubMed | Full Text | DOI]

10. Light RW, MacGregor MI, Luchsinger PC, Ball Jr WC. Pleural effusions: The diagnostic separation of transudates and exudates. Ann Intern Med. 1972 Oct;77(4):507-13. [PubMed | Full Text | DOI] 